\title{
Chimeric Antibody CHCC49
}

National Cancer Institute

\section{Source}

National Cancer Institute. Chimeric Antibody CHCC49. NCI Thesaurus. Code C28885.

A second generation murine monoclonal antibody with high affinity for the tumorassociated glycoprotein (TAG)-72, a human pancarcinoma antigen. Chimeric humanized CC49 (CHCC49) antibodies are generated through replacing the murine immunog lobulin (Ig) constant regions with the human constant regions of the heavy and light Ig chains, as well as through grafting CC49 hypervariable regions onto frameworks of the variable light (VL) and variable heavy (VH) regions of human monoclonal antibodies LEN and $21 / 28^{\prime} \mathrm{CL}$, respectively. Utilizing CHCC49 antibodies avoid anti-mouse immune response in human, which occured with the use of mouse CC49 antibody, but still exhibit the same affinity for human TAG-72 antigen, thereby resulting in strong radioimag ing activity when linked to a radioisotope. 